\title{
THE BENEFITS OF ADVANCED DATA ANALYTICS IN BASKETBALL: APPROACH OF MANAGERS AND COACHES OF LITHUANIAN BASKETBALL LEAGUE TEAMS
}

\author{
Julius Demenius, Rasa Kreivytè \\ Lithuanian Sports University, Kaunas, Lithuania
}

\begin{abstract}
Background. Many industries use a variety of statistical models for a decision-making, but no industry relies on analytical data as a professional sport (Davenport, 2014). Sports organization management and decision-making have a direct relationship with the sports teams and this relationship is called a comprehensive statistical analysis (Radovanović, Radojičić, Jeremić \& Savić, 2013). Alamar (2013) argues that a detailed statistical analysis of the game activities is an important aspect in order to more accurately assess the player's market value.

Methods. The sample consisted of 30 respondents (10 managers, 10 coaches, 10 coach assistants) of the 10 men's basketball teams. Managers and coaches of Lithuanian Basketball League teams had to fill in online questionnaire, the main focus of which was to identify their opinion about advanced data analytics. The questionnaire was designed based on scientific studies (Alamar, 2013; Martinez \& Martinez, 2011). Questionnaire scales were tested using SPSS 20.0 statistical analysis program.

Results. Statistical analysis showed that questionnaire reliability was average (Cronbach $\alpha=.549-.558)$. The survey results showed that the teams of Lithuanian Basketball League there employ professionals whose main goal is to analyse performance indicators, statistical data of opponents and new incoming players. Majority of managers and coaches believe that new information technologies of advanced basketball data could help improve team performance results and draw more attention to basketball from fans' perspective. It was found that managers and coaches thought that offensive strategy depends on the players of the team. Coaches and managers had a positive approach to basketball analytics and believed that it had a bright future in basketball industry.

Conclusions. The correct use of limitless data would definitely help improve team performance and effectively use their financial resources recruiting the most efficient players.
\end{abstract}

Keywords: statistical analysis, performance indicators, basketball.

\section{INTRODUCTION}

M any industries use a variety of statistical models for a decision-making, but no industry relies on analytical statistical data as a professional sport (Davenport, 2014). Sports organization management and decisionmaking have a direct relationship with the sports teams results and this relationship is called a comprehensive statistical analysis (Radovanović, Radojičić, Jeremić \& Savić, 2013). Presenting, developing and operating comprehensive statistical data is still one of the biggest challenges for organizations, but being able to understand such data would open big possibilities to improve productivity and also compete with other organizations (Alamar, 2013). Oliver (2004) suggests that advanced statistical data is an important aspect when we want to evaluate the player's true value in the market. However, Nikolaidis (2015) states that basketball team managers in Greece still do not understand that the quality of their decision-making could 
have a big impact on the use of club financial resources. Advanced game statistics analysis gives a possibility to make better evaluations of everything that happens in a basketball game (Sampaio, Janeira, Ibañez \& Lorenzo, 2006). Alamar (2013) has stated two comprehensive data statistics goals: 1) A well-built sports analytics program saves time for decision makers to make the most efficient decisions in terms of evaluating teams and players; 2) To receive comprehensive statistical data about teams and players and attain informative insights that would not be possible without advanced statistical data. STATS Sport VU camera's system (multi - lens tracking system) now is a very useful and productive system to analyse basketball games (YonggangNiu \& Zhao, 2014). Oliver (2004) introduced " 4 factors" that have a significant impact on team's chances to get a win: shooting, turnovers, rebounding, and free throws. Caporale \& Collier (2015) carried out research about shooting and they found that basketball teams should shoot more three-point shots. Goldman \& Rao (2013) believe that teams should take more three-point shots because of a simple reason -3 is more than 2 .

In this paper we examined the approach of managers and coaches of Lithuanian Basketball League (LKL) teams to advanced statistical data. While using advanced statistical data coaches could create and adapt more effective game strategies, also managers could have an opportunity to take a closer look at players' individual abilities and their value in the market. Research about basketball players and team performance analyses using comprehensive statistical data is new so far (Ergül, Yavuz \& Yavuz, 2014). Basketball analytics is a growing area in Europe, so only few (http://www.inthegame. org/ or www.draftexpress.com) websites have comprehensive data about players and teams from Europe (Martinez \& Martinez, 2011). In Lithuania Kreivyte and Čižauskas (2010) have carried out research about basketball statistics, but they only used fundamental statistical protocol data.

The aim of this study was to identify approach of managers and coaches of Lithuanian Basketball League teams to advanced data analytics in basketball.

\section{METHODS}

Participants. Exploration sample consisted of 30 basketball specialists from Lithuanian Basketball League (10 managers, 10 head coaches,
10 assistant coaches). The study aimed at including at least one of the specialists to participate in the survey from each club: Alytaus „Dzūkija“, Utenos „Juventus“, BC Panevèžio „Lietkabelis“, Vilniaus „Lietuvos Rytas“, Klaipèdos „Neptūnas“, Kèdainių „Nevėžis“, Pasvalio „Pieno žvaigždès“, Šiaulių „Šiauliai“, BC Prienu - Birštono „Vytautas“ ir Kauno „Žalgiris“. There were 4 international coaches working in Lithuanian Basketball League teams (head coach $n=1$, assistant coaches $n=3$ ). They could not participate in the survey because the questionnaire was in the Lithuanian language. Totally, 8 clubs participants attended the survey: 3 managers, 2 head coaches, 3 assistant coaches.

Procedure. An online survey link was sent to Lithuanian Basketball League team managers and front offices via e-mail on November 2, 2016. The questionnaire was closed, so only selected respondents were able to participate in the survey. Comprehensive basketball statistics and analytics were explained to them. The survey was anonymous.

Measures. The main object is comprehensive data analysis and the value of it. In this research we used a mixed study design (quantitative and qualitative research methods) - data collecting, questionnaire survey, generalization of answers using statistical methods, reflection of people's opinions (Kačerauskas, 2014). Online questionnaire was used and it was constructed using information about comprehensive statistical data from theory and partly from scientific articles and research (Alamar, 2013; Martinez \& Martinez, 2011), also using made up questions. The goal of the questionnaire survey was to learn about the approach of managers and coaches. The questionnaire consisted of 11 questions, where respondents could have picked one or few answer options. The structure of questionnaire was as follows: 8 closed type questions (quantitative when a respondent had to choose one or few answers) and 3 open type questions (qualitative when a respondent could write their own answer).

Data analysis. Questionnaire scales were verified using SPSS for Windows 20.0 statistical analysis program. Statistical analysis showed that questionnaire reliability was average (Cronbach's $\alpha=.549-.558$ ) (Table). Internal consistency of the main questionnaire scales was calculated. Cronbach's $\alpha$ of the Opponents and Individual Players' Analysis and Playing Strategy Scale was .549. Cronbach's $\alpha$ of the Use of New Technology Scale was .558. 
Table. The criteria for the internal consistency of the scales

\begin{tabular}{|l|c|c|}
\hline \multicolumn{1}{|c|}{ Scales } & Number of statements & Cronbach's alfa coefficient \\
\hline $\begin{array}{l}\text { Opponents and Individual Players } \\
\text { Analysis and Playing Strategy (Scouting) }\end{array}$ & $n=17$ & .549 \\
\hline The Use of New Technology & $n=12$ & .558 \\
\hline
\end{tabular}

\section{RESULTS}

First question was "Is there a person or people (scouts) whose main focus are opponents and individual players' analysis?" and even $66.7 \%$ of respondents answered that team coaches did analysis and $33.3 \%$ of respondents said that their club had scouts whose main focus was to analyse video and data of opponents and individual players. The research results revealed that there were no significant differences between managers, head and assistant coaches in terms of their answers about the people whose main focus was opponents' and individual players' analysis $(p>.05)$. So, the first question showed that in LKL teams, coaches and scouts did opponents' and players' analyses, but off-season managers and clubs' front offices were collectively looking for new players and making decisions about team roster. Even $25 \%$ of respondents said that head coach and team front office was responsible for taking new team players; $25 \%$ respondents said that the whole coaching staff, head coach and team front office were responsible for taking new free agents; $50 \%$ of respondents noted that all coaching staff were responsible for team roster construction. The research results revealed that there were no significant differences between managers, head and assistant coaches in terms of who was responsible for team roster decisions $(p>.05)$. The survey included a question how teams performed opponents' and new individual players' analysis. After the survey it was clear that $35.3 \%$ of clubs watched videos and evaluated players with an "eye test", also the same percentage (35.3\%) of respondents said that teams performed advanced statistical data analysis (player offensive rating, effective field goal percentage (eFG\%), number of dribbles before attacking, offensive and defensive rebounding). $29.4 \%$ of teams peerformed traditional game statistics analysis. Participants were asked what value to their team new technologies could bring. One of four $(25 \%)$ of respondents believed that new information technologies would help to analyse basketball more deeply and it would help to improve teams results. Also one of four $(25 \%)$ of respondents believed that new technologies would help to save money for teams (looking for new and efficient players) and one third of respondents $(33.3 \%)$ said that they would love to have new information technologies and it would improve their abilities to evaluate players; $16.7 \%$ of respondents believed that new information technologies would help to improve players' and team performance and potential (Figure 1).
Figure 1. Respondents'answers of perceived value indicators

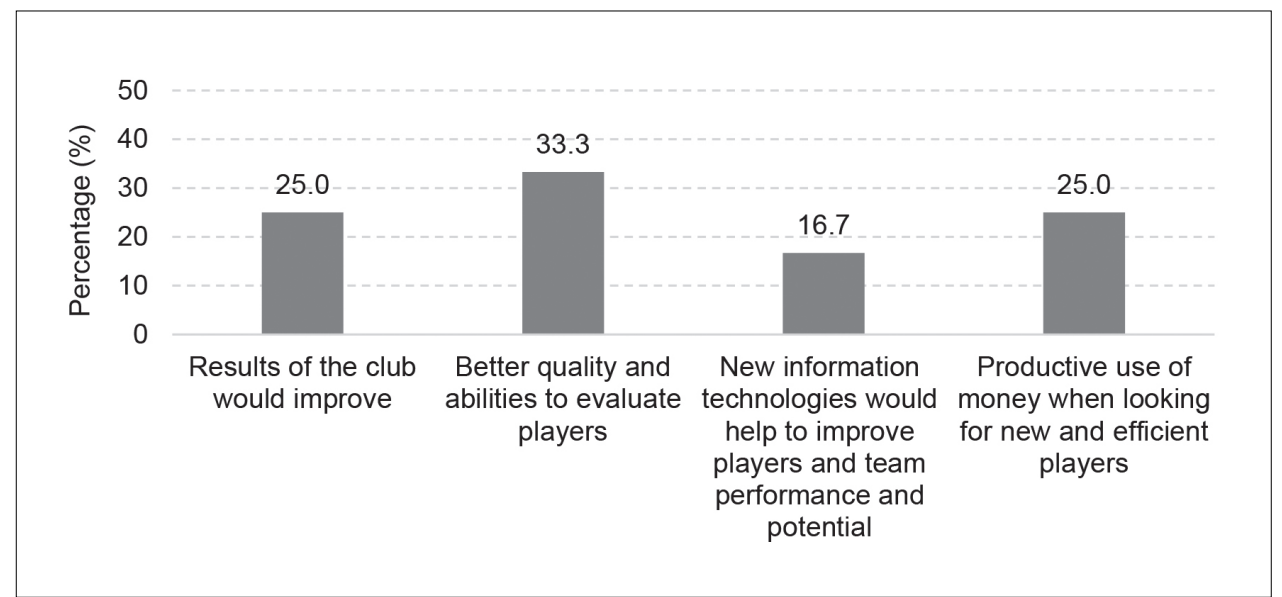




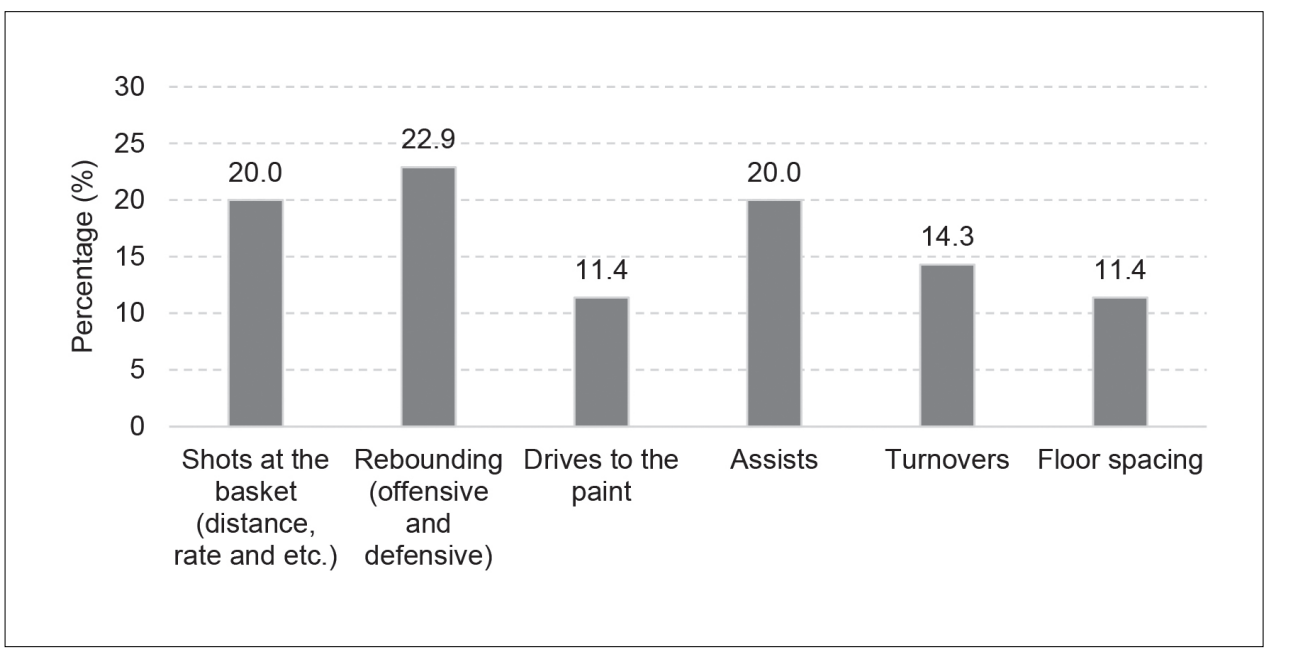

Figure 2. Indicators to be analysed first

If managers and coaches could have the newest information technologies, the first data indicators, they would like to analyse: $22.9 \%$ rebounding, $20 \%$ shooting - distance, rate, location on the court, type of shot: jump shot, floater, the hook, dribbles before a shot, last second shots. Also, $20 \%$ would look in assist category, $11.4 \%$ drives to the painted area, $14.3 \%$ turnovers, $11.4 \%$ spacing on the floor (Figure 2).

Respondents were asked to write their opinion about basketball offensive strategy, where the main focus is to make shots close to the basket and three point shots. Six respondents gave their answers., two respondents said that coaches should think about what type of players they had first and then make the best strategy for them: "Offensive strategy depends on the players you have: shooters, skilled big mans, fast and quick guards"; "There is no one strategy. Every coach and player is unique, so offensive strategy should be adjusted to the players you have". One of the managers agreed that game offensive strategies and elements are changing in Europe and the main influence is National Basketball Association (NBA) teams: "Basketball is changing and the main influence is $N B A$ ". Two respondents agreed that the mid-range shot is still very useful in basketball: "I don't see a problem attacking from mid-range area in games, especially when power forwards and centres these days could attack from mid - range and spread the floor"; "I think that all types of shots are very useful in basketball". One of respondents did not see anything special from this type of strategy: "Nothing special".

Respondents had a possibility to write their opinion about advanced data analytics and its influence to basketball community. The total of 7 specialists answered: 4 specialists had a positive opinion about advanced data analytics and thought that comprehensive data ccould help to attract more people to play and be a part of basketball community: "Maybe a new way of analytics can show people a different and interesting perspective to basketball"; "Of course"; "Basketball community are able to gather more information about basketball"; "Yes". Two respondents thought that advanced data analytics could help to analyse opponents better: "In this day of age, small details could have a big influence which team will be able to win. It is important to know opponents offensive and defensive tactics and their weaknesses. Prepared team have an opportunity to perform an analysis and become more professional in what they do, also have a better chance to play at the highest level"; It helps to reveal strengths and weaknesses of opponents". One respondent thought that there was no need to use advanced data statistics and the best way to evaluate a player was just to look at his shooting percentage: "I understand the value of player by his shooting statistics: he score 20 points by shooting 13 shots and other example - player score 20 points, but by shooting 23 shots".

Only one respondent out of seven who expressed their opinion said that he was not sure if basketball analytics had a future in basketball: "I don't know", but other 6 specialists believed that basketball analytics was and would be very useful: "It is going to help evaluating players and their skills"; "Yes"; "Yes"; "Yes, because basketball is evolving"; "Basketball analytics would be very useful, but at first they have to prove teams, that their information and methods could help to win 
games"; "In this industry (basketball) just the highest level teams have a possibility to have various types of basketball specialists on their teams. I think that basketball analytics and scouts have a bright future in basketball because the majority of teams are doing several of opponent's analysis, but basketball analytics specialists have to understand not only math and numbers, but also basketball in general".

\section{DISCUSSION}

Online survey results showed that clubs from Lithuanian Basketball League performed various basketball analysis and teams used some kind of basketball advanced data analysis, so it can be stated that there is a positive approach towards comprehensive basketball statistical data. Basketball is the most popular sports in Lithuania, that it is natural there is a lot of attention and money dedicated to basketball and teams are trying to be competitive in Lithuanian and European leagues. Basketball advanced data analytics is widely spread in all of NBA teams (30), where every team has their own basketball analytics specialist team. Teams spend a lot of money for having newest information technologies and media using basketball advanced data to write more informative articles about basketball. However but comprehensive data statistics is still a new area of basketball in Europe (Martinez \& Martinez, 2011). There is still a lot of questions on how to use all of the advanced data while creating new playing strategies and evaluating individual players. The majority of team managers and coaches confirmed that they were combining video, "eye test" and advanced basketball data. Alamar (2013) had similar results in his research, where respondents said that they were using 3-4 methods for statistical analysis.

This research shows that there is a need for new information technologies for basketball clubs. Specialists from basketball teams believe that new information technologies would be very beneficial and useful: better evaluation of opponents and individual players, team results could improve, a search for new player would be more productive and clubs could spend money on new players more efficiently. Eschker, Perez and Siegler (2004) established that NBA teams hadpaid 2 times more money than they should have because of lack of information and new technologies. Comprehensive data analysis would provide better opportunities to analyse new potential players' skill sets and would be beneficial in looking for new ways on how to improve team performance during basketball season in highest level competition.

Caporale \& Collier (2015), Nikolaidis (2015), Shea (2014) all collectively maintain that teams should avoid mid - range shots and shoot more close to the basket shots and three pointers, but this trend is still not used in Lithuanian basketball clubs because the majority of LKL clubs managers and coaches think that mid - range shots are still very important in basketball. It is worth mentioning that some respondents think that coaches have to adapt offensive strategies to players and not vice versa, but Houston „Rockets“ were able to be at a competitive position in NBA even when they lost 2 All - star players because of the strategy where the team shoots a lot of shots close to the basket, free throws and three pointers.

The majority of respondents have an opinion that advanced basketball data analytics has a bright future in basketball industry, but for now just only the highest level teams have an opportunity to have that kind of technologies and specialists. It has to be a specialist who understands numbers, math and basketball. Also, he/she needs to find ways how to present advanced statistical data to coaches and prove that this type of data could be helpful and useful for improving and making their game strategy more efficient for team performance. Advanced basketball data analytics should be interesting not only for the best clubs in Lithuania, but also for lower level league teams. Teams use limited amount of resources (money), so advanced statistical data information could help to spend money for team roster more efficiently. It is worth saying that LKL team managers and coaches think that advanced data analytics specialists have a bright future in basketball industry.

To sum up, it can be stated that managers and coaches of Lithuanian Basketball League teams have a positive approach to basketball analytics and its future. However, there are a lot of limitations for doing a more comprehensive research in this field because of the lack of data and other scientific research. Basketball analytics is widely used in NBA. Teams are playing in analytical way and creating new front office positions for basketball data specialists. Basketball analytics is just a growing area in Europe (Martinez \& Martinez, 2011). It is important for team managers to find ways how to use club resources in the most efficient 
way, find players and evaluate their use on the court and value in the market. More basketball related comprehensive data would be beneficial for managers' decision-making.

\section{CONCLUSIONS}

New information technologies could help to improve opponents' and new individual players' analysis. Club teams would be able to use their resources (money) more efficiently. Respondents were asked to write their opinions about basketball offensive strategy, where the main focus is to make shots close to the basket and three point shots, and it was found that managers and coaches thought that offensive strategy depends on the players a coach has and that mid - range shot is a very efficient shot at basketball. It was found that advanced basketball data analytics specialists have a bright future in basketball industry.

\section{REFERENCES}

Alamar, B. (2013). Sports analytics: A guide for coaches, managers, and other decision makers. New York: Columbia University Press.

Caporale, T., \& Collier, T. C. (2015). To three or not to three? Shot selection and managerial performance in the National Basketball Association. Journal of Labor Research, 36, 1-8. doi: 10.1007/s12122-014-9193-5.

Davenport, T. (2014). Analytics in sports: The new science of winning. International Institute for Analytics White paper. Portland: IIA.

Ergül, B., Yavuz, A. A., \& Yavuz, H. S. (2014). Classification of NBA League teams using discriminant and logistic regression analyses. Pamukkale Journal of Sports Sciences, 5(1), 48-60.

Eschker, E., Perez, S. J., \& Siegler, M. V. (2004). The NBA and the influx of international basketball players. Applied Economics, 36(10), 1009-1020. doi: 10.1080/0003684042000246713

Goldman, M., \& Rao, J. M. (2013). Live by the three, die by the three? The price of risk in the NBA. Submission to the MIT Sloan Sports Analytics Conference. Retrieved from www.sloansportsconference.com

Kačerauskas, T. (2014). Kūrybos visuomenès terminai ir sampratos. Logos, 78, 6-18.

Kreivytė, R., \& Čižauskas, A. (2010). Varžybinès veiklos rodiklių skirtumai tarp laimejjusių ir pralaimejjusiu krepšinio komandu. Ugdymas. Kūno kultūra. Sportas, 77(2), 41-48.

Martinez, J. A., \& Martínez, L. (2011). A stakeholder assessment of basketball player evaluation metrics. Journal of Human Sport \& Exercise, 6(1), 153-183. doi: 10.4100/jhse.2011.61.17

Nikolaidis, Y. (2015). Building a basketball game strategy through statistical analysis of data. Annals of Operations Research, 227(1), 137-159. doi: 10.1007/ s10479-013-1309-4.

Oliver, D. (2004). Basketball on paper: Rules and tools for performance analysis. Potomac Books, Inc.

Radovanović, S., Radojičić, M., Jeremić, V., \& Savić, G. (2013). A novel approach in evaluating efficiency of basketball players. Management, 67, 37-45. doi: 10.7595/management.fon.2013.0012

Sampaio, J., Janeira, M., Ibánez, S. \& Lorenzo, A. (2006). Discriminant analysis og game-related statistics between basketball guards. Forwards and centres in three professional leagues. European Journal of Sport Science, 6(3), 173-178. doi: 10.1080/17461390600676200

Shea, S. M. (2014). Basketball Analytics: Spatial Tracking. San Bernardino, California.

YonggangNiu, H. H., \& Zhao, H. (2014). Application of the Sport VU Motion Capture System in the Technical Statistics and Analysis in Basketball Games. Asian Sports Science, 3(7), 45-52.
Corresponding author Julius Demenius

Lithuanian Sports University

Sporto str. 6, LT-44221 Kaunas Lithuania

Tel. +37063070175

Email julius.demenius@gmail.com 